\title{
Latitude and coastline shape correlate with age-structure of Chlorostoma (Tegula) funebralis populations
}

\author{
Erin E. Cooper*, Alan L. Shanks \\ University of Oregon, Oregon Institute of Marine Biology, PO Box 5389, Charleston, Oregon 97420, USA
}

\begin{abstract}
Between 2005 and 2008, size-frequency distributions from 22 populations of the intertidal snail Chlorostoma (Tegula) funebralis were studied to determine the effects of latitudinal region and coastal topography. Upwelling, which may affect larval recruitment, varies along a latitudinal gradient, while coastal topography may mitigate the effects of latitude. Sites were categorized by latitude: Northern (Oregon, 15 sites), and Southern (California, 5 sites; Baja California, 2 sites); and by coastal topography: protected (bays and coves, 7 sites in north, 3 in south), or exposed to the open ocean ( 7 sites in north, 5 sites in south). In Oregon, population structures at protected and exposed sites were significantly different $(p=0.001)$. At protected sites, a large percentage of individuals were pre-reproductive juveniles. At exposed sites, the population was weighted towards large individuals capable of high reproductive output with few juveniles present in the population. This pattern may reflect inter-annual variation in recruitment in Oregon, with protected areas experiencing more constant recruitment. In California and Baja California all populations were predominately composed of juveniles, regardless of coastal topography $(p=0.336)$. Differences in age-structure of the population create significant differences in relative reproductive potential. The potential reproductive output of a population was calculated by quantifying the eggs produced by snails covering the size range of reproductive individuals. Populations in the north at exposed sites produce eggs at a rate up to 2 orders of magnitude higher than populations in the south $(p=0.004)$. These variations in size-structure of $C$. funebralis populations with coastal topography and latitude may have important impacts for the population distribution.
\end{abstract}

KEY WORDS: Population dynamics $\cdot$ Age structure $\cdot$ Chlorostoma funebralis $\cdot$ Recruitment

\section{INTRODUCTION}

The size-frequency distributions and age structures of many marine invertebrates vary between populations (Ebert \& Russell 1988, McQuaid \& Phillips 2006). At times, these attributes vary along a latitudinal gradient (Frank 1975, Ebert 1983, Menge et al. 2004). These differences may be the result of larval supply and recruitment, since years of poor recruitment will result in gaps in the size-frequency distribution as the population ages (Ebert \& Russell 1988, Roughgarden et al. 1988, Menge et al. 2004). Differences in recruitment, in turn, may be driven by hydrodynamics and coastal topography. As larvae have limited swimming capacity, their movement may largely be determined by the movement of water masses, which can vary latitudinally as well as locally. Frank (1975) and Wright (1975) collected data on the size distribution of Chlorostoma (Tegula) funebralis along the west coast of North America. These distributions showed a latitudinal gradient in the number of adult individuals, with the largest number of adults in the northern populations and more juveniles in southern populations. However, populations for these studies were geographically disparate and coastal topography was not incorporated into the experimental design. To distinguish between latitudinal gradients that might be driven by changes in coastal hydrodynamics and the 
effects of coastal topography, more sampling of more populations over a larger latitudinal range and different coastal topographies is necessary.

The intertidal snail Chlorostoma (Tegula) funebralis is an ideal organism to study variation in sizefrequency distributions because it is common and often abundant in the rocky intertidal from Baja, California to British Columbia in both high and low energy environments (Morris et al. 1980). The duration of the pelagic lecithotrophic larval stage is between 5 and $8 \mathrm{~d}$ (Moran 1997, Guzmán del Próo et al. 2006). Individuals live up to $30 \mathrm{yr}$ in the northern portion of the range (Darby 1964) and 6 to $7 \mathrm{yr}$ in the southern portion of the range (Frank 1975). Growth rates have been calculated throughout the species range (Frank 1975, Wright 1975). C. funebralis grow throughout their lifespan, so it is possible, using size, to age individuals and use size-frequency distributions as an indication of age structure of populations (Frank 1975). The differences in the number of adults in populations of $C$. funebralis along a latitudinal gradient (Frank 1975, Wright 1975) present an opportunity to study the mechanisms of population structure.

Larval supply can drive patterns in recruitment and adult distributions (Ebert \& Russell 1988, Roughgarden et al. 1988, Menge et al. 2004). Populations with low larval supply have been shown to have low population densities. This relationship between larval supply and population structure has been seen, for example, in urchins (Ebert \& Russell 1988), mussels (McQuaid \& Phillips 2006) and barnacles (Menge et al. 2004). The recruitment of many marine invertebrate larvae to adult populations is driven by hydrodynamics both large-scale and local. Species with a planktonic larval stage have a dispersal distance determined by hydrodynamics, larval duration, and larval swimming behavior, primarily vertical migration (Shanks et al. 2003, Shanks 2009). Upwelling, which moves surface waters offshore, is hypothesized to move larvae away from benthic habitats where they must ultimately settle (Roughgarden et al. 1988). When upwelling is relaxed, surface waters move back towards the shore, carrying larvae back to the adult habitat. Larval capacity for vertical migration may be a confounding factor, enabling larvae to stay nearshore even during upwelling events (Poulin et al. 2002, Shanks \& Brink 2005, Morgan et al. 2009a,b, Shanks \& Shearman 2009). Larvae may also have a preference for depths below the Ekman transport layer, which would minimize movement offshore during upwelling (Shanks \& Brink 2005, Morgan et al. 2009a,b, Shanks \& Shearman 2009).

On the west coast of North America, coastal upwelling varies on a latitudinal gradient. Summer winddriven upwelling is intermittent on the Oregon Coast south to Cape Blanco, and relatively constant from
Cape Blanco to Point Conception (Roughgarden et al. 1988). Roughgarden et al. (1988) hypothesized that the intermittent upwelling in central and northern Oregon should transport pelagic larvae to the rocky intertidal, reducing larval mortality and causing constant, annual larval supply. More constant upwelling in central and northern California should transport larvae offshore, resulting in delivery of larvae to the shore only under rare conditions (Menge et al. 2004).

Coastal topography has also been shown to affect larval dispersal and settlement. As many types of larvae have limited swimming capability, local, smallerscale oceanographic features may play a role in retaining larvae or moving them offshore. Ebert \& Russell (1988) and Morgan et al. (2000) found a correlation between coastal headlands and larval recruitment. Sites with low recruitment were near coastal headlands, where regular coastal upwelling jets are hypothesized to move larvae offshore. In South Africa, protected bays and exposed headlands have different population structures of mussels, possibly related to recruitment patterns. Higher recruitment in bays in comparison to nearby exposed populations may be due to larval retention within the bay and larval advection from exposed sites (von der Meden et al. 2008). The flushing times of bays is correlated with retention of cyprid larvae (Gaines \& Bertness 1992). In one study, the presence of oceanographic fronts at the mouths of bays and coves was correlated with upwelling, and the fronts acted as a barrier to the shoreward movement of larvae into the bay (McCulloch \& Shanks 2003).

The distribution of adult marine invertebrates is the cumulative effect of recruitment success, juvenile mortality, and adult mortality. Each of these factors may vary between populations independently of each other. Previous studies have shown that large Chlorostoma funebralis are absent in the southern portion of the species range when compared to the northern portion of the species range (Frank 1975, Wright 1975). This absence may be a reflection of a latitudinal gradient in adult mortality, but not enough populations have been studied to determine the potential effects of other factors. The presence of large adults in the population may have a significant impact on the reproductive capacity of the population (McQuaid \& Phillips 2006) and so is important to understand.

Previous studies of Chlorostoma funebralis did not sample enough sites within each oceanographic region to separate the confounding effects of upwelling and coastal topography on population structure. Frank (1975) sampled 6 sites in the northern portion of the range and 5 in the south. In the present study, 22 sites covering a wide latitudinal range and 2 types of coastal topographies were sampled for the size-frequency distributions of populations of $C$. funebralis to separate the im- 
pact of upwelling and coastal topography. If upwelling, through its impact on larval dispersal, is driving patterns of population structure, differences in population structure should be observed in regions with different upwelling strength and duration, as shown by differences in latitudinal regions. If population structure is caused by coastal topography affecting larval dispersal, differences within regions with similar upwelling regimes should vary with the type of coastline. While hypotheses for the mechanisms driving population structure abound, without detailed descriptions of these patterns, appropriate mechanisms cannot be tested.

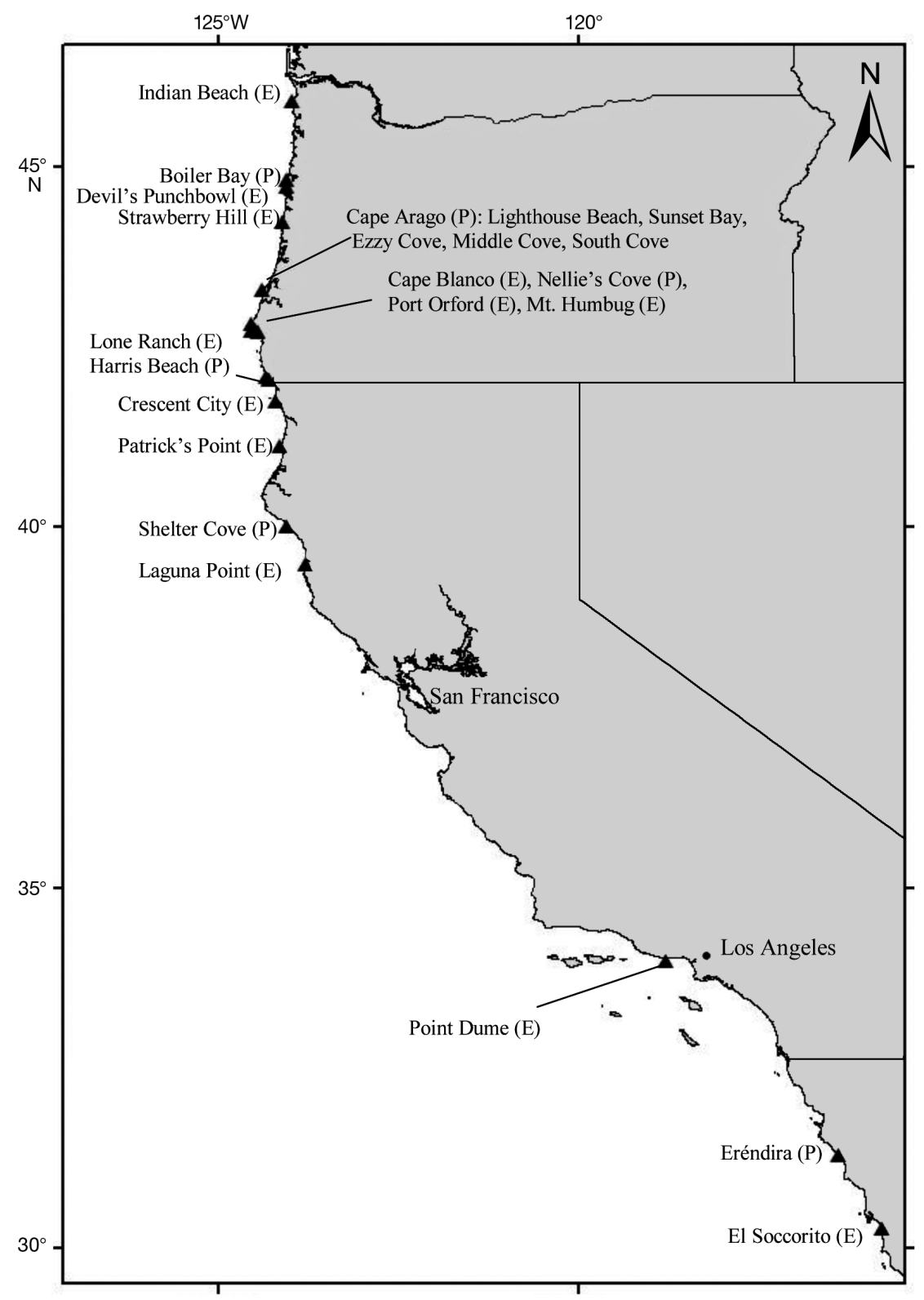

Fig. 1. Map of west coast of North America, showing 22 exposed (E) or protected (P) sites from which Chlorostoma funebralis were collected. Horizontal line represents Oregon/California boundary

\section{MATERIALS AND METHODS}

Site classification. To investigate if population structure changes with coastal topography, populations were sampled at 'protected' and 'exposed' sites. Sites identified as protected included bays and coves predominately enclosed on at least 3 sides. Exposed sites were exposed to the open ocean on 2 or more sides. The wave energy of sites may differ within exposure classifications due to changing hydrographic conditions along the coast of North America, so classification is an indication of the shape of the local coastline and not an indication of local wave energy.

Sites were classified as 'north' or 'south' based on the geographic range of the large ( $>5 \mathrm{~g}$ ) adult Chlorostoma funebralis. Initially, populations were identified as north or south of Cape Blanco, the traditional breakpoint between regions of intermediate (north of Cape Blanco) and constant upwelling (south of Cape Blanco) (Barth et al. 2000). However, the geographic distribution of populations including large individuals has a southern limit of Brookings, Oregon, approximately $100 \mathrm{~km}$ south of Cape Blanco.

Site selection. Twenty-two populations of Chlorostoma funebralis from northern Oregon to Baja, California, were sampled (Fig. 1, see Table 1). Sampling was conducted during the summers of 2005 and 2006, with the exception of sites in Baja, California, which were sampled during the winter of 2005. Sites were selected by the presence of $C$. funebralis habitat, primarily mid to high rocky intertidal, and the ease of accessibility. Sites were selected throughout this range to test for a latitudinal gradient in size-frequency distributions.

In Oregon, 15 sites were sampled (8 protected, 7 exposed), all considered part of the northern portion of this study. Five of these sites (Lighthouse Beach, Sunset Bay, Ezzy Cove, Middle Cove, South Cove) are found near Cape Arago, Oregon. In the southern portion of the study, 4 sites were sampled in northern California (3 exposed, 1 protected), 1 in southern California (exposed), and 2 in Baja (1 protected, 1 exposed, Fig. 1).

Sampling populations. Because Chlorostoma funebralis settle into the 
high intertidal and migrate into the mid intertidal as they grow larger, sampling was conducted with a belt transect across tidal heights. The width of the transect was selected based on the density of individuals at that site $(0.25,0.5$, or $1 \mathrm{~m}$ width). In populations with low densities $\left(<20\right.$ ind. $\left.\mathrm{m}^{-2}\right)$, a wide transect was used (up to $1 \mathrm{~m}$ ) to ensure that an adequate number of individuals were sampled on each transect. In areas with high densities, narrower transects $(0.25$ or $0.5 \mathrm{~m})$ were used. A minimum of 3 transects and 500 individuals were sampled at each site when possible. Transects were a minimum of $50 \mathrm{~m}$ apart to ensure independent sampling. If after sampling 3 transects, fewer than 500 individuals were sampled, additional transects were sampled. Indian Beach and Port Orford were too small to use more than 3 transect lines, so fewer than 500 individuals were collected from these 2 sites. The smallest juveniles (ca. <1 g) were collected by hand-sorting coarse sediment taken from under boulders in the high intertidal. Larger juveniles and adults were collected from under and on boulders, in tide pools, and under algae.

All individuals within the belt transect were collected and allowed to air dry. Initially, individuals were weighed and shell diameters were measured at the widest point across the umbilical region from the shell lip to the opposite body whorl (Frank 1975). After weighing and measuring the width of 700 individuals, a power relationship was obtained between snail mass and shell diameter (Fig. 2). These data were logtransformed and the regression was found to be significant $\left(p<0.0001, R^{2}=0.916\right)$. After these initial measurements, weight alone was used to measure the size of individuals as this was the more efficient method of quantifying size. The age of individuals was calculated using growth rates and size-age correlation models along a latitudinal gradient published by Frank (1975).

To test for differences in population structure between sites of differing coastal topography, the per-

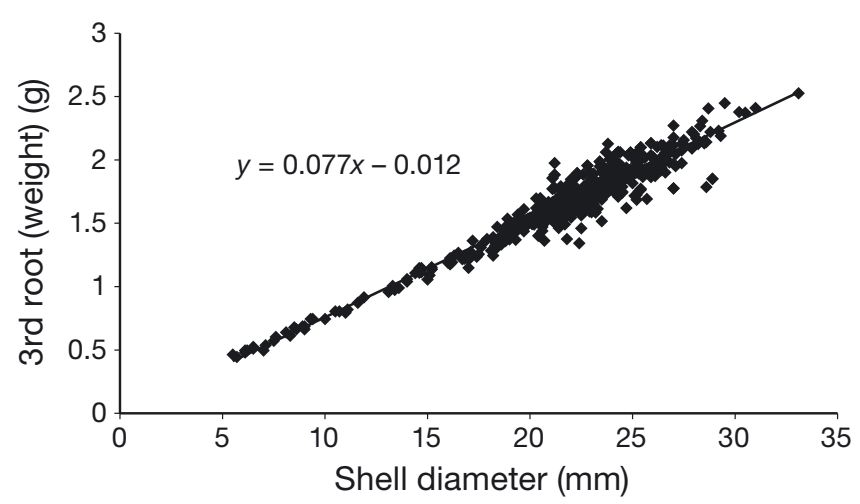

Fig. 2. Chlorostoma funebralis. Regression $\left(\mathrm{p}<0.0001, \mathrm{R}^{2}=\right.$ 0.916) between mass and maximum shell diameter centage of juveniles in each population was calculated after minimum size at reproduction was established from reproductive output data (see 'Reproductive output' below). To test for population differences on a latitudinal gradient and interaction with coastal topography, populations were tested using a 2-way ANOVA with latitudinal region and coastal topography as factors and the percentage of juveniles as the dependent variable. Further analyses using 1-way ANOVAs were used to test differences within latitudinal regions.

To test for differences in size distributions between sites, the coefficient of variation (CV) was used (Ebert \& Russell 1988). CV was calculated and arcsinetransformed for each population. Differences between latitudinal region and coastal topography as factors and $\mathrm{CV}$ as the dependent variable were tested using 1way and 2-way ANOVAs.

To test for differences in latitudinal gradient in the largest size classes, the percentage of the population that was $10 \mathrm{yr}$ of age or older $(9 \mathrm{~g})$ was calculated using growth rates published by Frank (1975). The percentage of these old individuals in each population was tested using the same statistical methods as the percentage of juveniles.

Reproductive output. To quantify the potential reproductive consequences of differing size-frequency distributions, the number of eggs per female Chlorostoma funebralis was calculated for individuals sized between sexual maturity and the largest individuals collected. Individuals between 2 and $15 \mathrm{~g}$ were collected from South Cove and Boiler Bay (northern region), Crescent City, Patrick's Point, Shelter Cove, and Laguna Point (southern region). These sites represent a combination of exposed and protected sites (Fig. 1). Throughout the species range, females smaller than ca. $2.0 \mathrm{~g}$ (ca. $14 \mathrm{~mm}$ in diameter) had gonad tissue with very few eggs (E. E. Cooper pers. obs.) and were judged sexually immature. Spawning is expected to take place in late summer or early fall (Belcik 1965, Paine 1971, Moran 1997), so collections were made in late July or early August, the period estimated to be prior to spawning but close enough to have reproductive individuals.

After weight and shell diameter was established, the female gonad was removed, weighed, and displacement volume measured. Ovaries were diluted and suspended in seawater. Four $20 \mu \mathrm{l}$ aliquots were sampled from each female and the number of eggs in each aliquot quantified. The aliquot was placed on a slide and gently pressed with a cover slip. A digital camera was used to photograph the sample under $4 \times$ magnification. ImageJ (Rasband 1997-2008) was used to superimpose a grid over the image to increase the accuracy of enumeration of eggs in the sample. All of the eggs in the entire $20 \mu$ laliquot were counted. 
With few exceptions, replicate aliquots from females were not significantly different from each other and so were averaged. Total egg production was calculated based on egg concentration in $20 \mu$ laliquots times the total ovary mass suspended in seawater. A linear regression was used to test the association of number of eggs in the gonad and the size of the individual. Sexually immature individuals $(<2 \mathrm{~g})$ were excluded from this analysis.

\section{RESULTS}

\section{Size-frequency distributions}

Size-frequency distributions were collected from 22 sites along the west coast of North America (Fig. 3). The number of individuals measured from a population ranged from 79 to 4564 and were collected from between 3 and 5 independent transect lines. Sites were grouped by coastal topography (protected or exposed) and latitudinal range (north or south of Brookings, Oregon, see 'Materials and methods'). Two size-frequency distributions (those weighted towards juveniles and those lacking large numbers of juveniles) were apparent in populations north of Brookings. Populations also varied in the presence or absence of large individuals (>5 g). In populations south of Brookings, all were weighted towards the juvenile size classes $(<2 \mathrm{~g})$ and most populations had few individuals larger than $5 \mathrm{~g}$.

\section{Proportion of juveniles}

When a 2-way ANOVA was used with coastal topography and latitudinal region as factors, the differences based on coastal topography were not significant $\left(F_{\mathrm{s}}=1.190, \mathrm{df}=1, \mathrm{p}=0.290\right)$. The difference between north and south was significant $\left(F_{\mathrm{s}}=10.573\right.$, $\mathrm{df}=1 \mathrm{p}=0.004)$ as was the interaction $\left(F_{\mathrm{s}}=5.977, \mathrm{df}=\right.$ $1, \mathrm{p}=0.025)$.

The results of the 2-way ANOVA potentially mask differences within latitudinal region. A 1-way ANOVA testing coastal topography on populations limited to the northern portion of the range (Brookings, Oregon, to Indian Beach, Oregon) showed a significant effect of coastal topography on population structure $\left(F_{\mathrm{s}}=\right.$ 9.183, df $=1, \mathrm{p}=0.021$ ). Protected populations were heavily weighted towards juveniles, with populations averaging $59 \%$ juveniles. Exposed populations had few individuals in the juvenile size classes, averaging just $14 \%$ of individuals. In the northern portion of the range, the only protected site that was not skewed towards juveniles was Nellie's Cove, near Port Orford,
Oregon. This site had no juveniles, but a large percentage of older individuals. When this site was removed from the 1-way ANOVA, the difference in the relative abundance of juveniles between protected and exposed sites increased $\left(F_{\mathrm{s}}=25.267, \mathrm{df}=1\right.$, $\mathrm{p}=0.001$ ).

In the southern portion of the range, Brookings, Oregon, to Baja California, there was no significant difference in the proportion of the population that were juveniles between protected and exposed sites using a 1 -way ANOVA $\left(F_{\mathrm{s}}=0.958, \mathrm{df}=1, \mathrm{p}=0.360\right)$. All sites comprised mainly juveniles with very few sexual mature individuals. Protected populations had an average of $69 \%$ juveniles, compared to exposed populations with $87 \%$ juveniles.

When Nellie's Cove was removed from the 2-way ANOVA, the significance in coastal topography increased, but was still not statistically significant $\left(F_{\mathrm{s}}=\right.$ 3.935, $\mathrm{df}=1, \mathrm{p}=0.064)$; however, the strength of the interaction effect increased $\left(F_{\mathrm{s}}=13.715, \mathrm{df}=1, \mathrm{p}=\right.$ 0.002).

\section{Coefficient of variation}

The CV is a measure of the dispersion of the sizefrequency distribution (Table 1). When the CVs of populations were analyzed with a 2-way ANOVA, the results were similar to those of the percentage of the population in the juvenile size range. The difference between north and south was significant $\left(F_{\mathrm{s}}=5.005\right.$, $\mathrm{df}=1, \mathrm{p}=0.038)$, the difference between protected and exposed sites was not significant $\left(F_{\mathrm{s}}=3.407, \mathrm{df}=1\right.$, $\mathrm{p}=0.081$ ), and the interaction between latitudinal range and coastal topography was significant $\left(F_{\mathrm{s}}=\right.$ 4.788, df =1, p=0.042).

When analyses are separated by latitudinal region and the effects of coastal topography are tested using 1-way ANOVAs, the results are again similar to those of the percentage of juveniles in populations. In the northern portion of the range, the difference in $\mathrm{CV}$ between exposed and protected sites was significant $\left(F_{\mathrm{s}}=11.273, \mathrm{df}=1, \mathrm{p}=0.006\right)$. Exposed sites, which had a range of sizes of large individuals, had large CVs in comparison to protected sites, which had primarily small individuals (Table 1). In the southern portion of the range, CVs were not significantly different between protected and exposed sites $\left(F_{\mathrm{s}}=0.044\right.$, df $=1$, $\mathrm{p}=0.841)$.

As with the percentage of the population in the juvenile size range, the significance of the CV changes with the exclusion of Nellie's Cove. When Nellie's Cove was removed from the 2-way ANOVA, the latitudinal difference was no longer significant $\left(F_{\mathrm{s}}=4.182\right.$, $\mathrm{df}=1, \mathrm{p}=0.057$ ), coastal topography became signifi- 

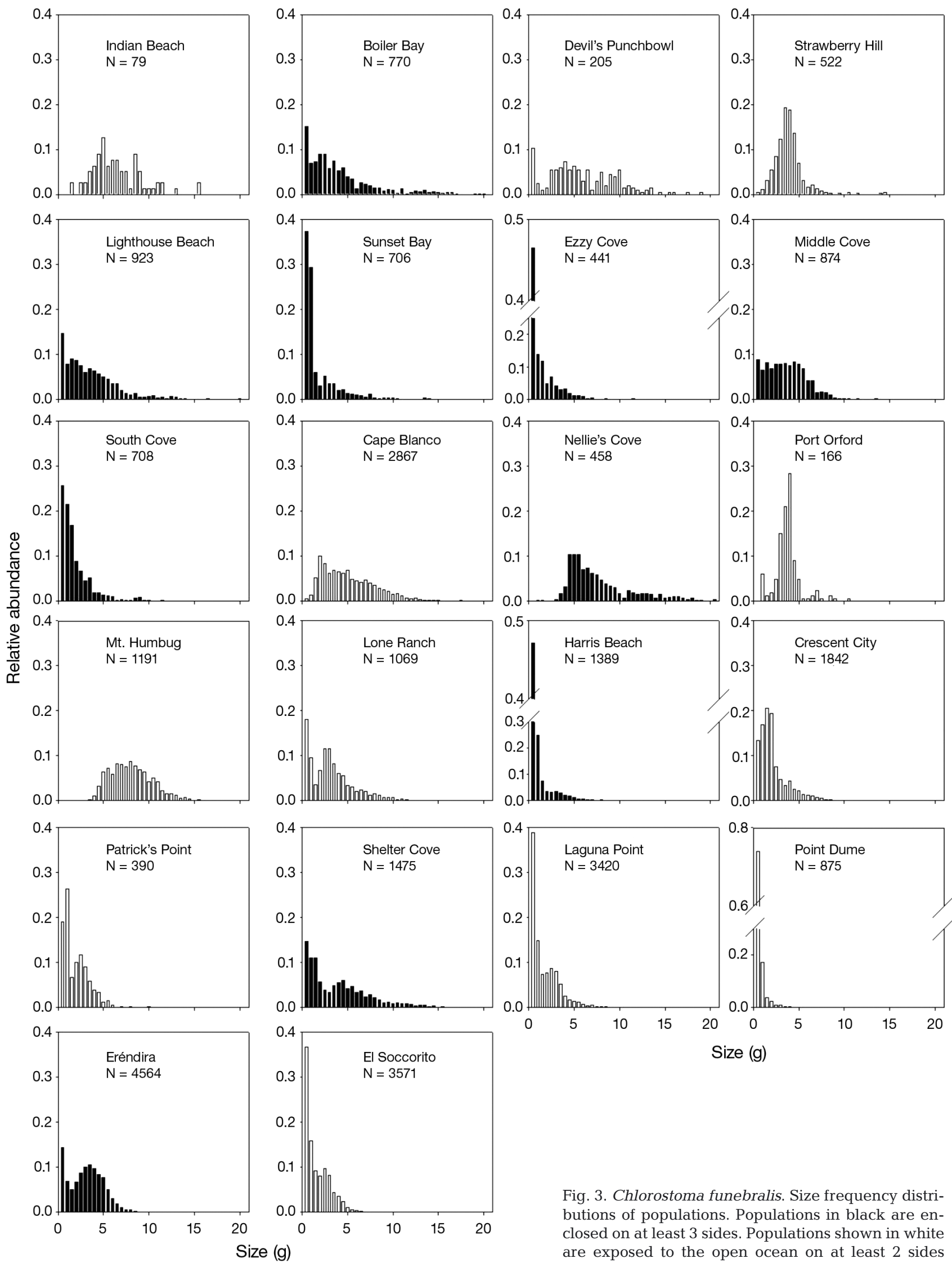

Fig. 3. Chlorostoma funebralis. Size frequency distributions of populations. Populations in black are enclosed on at least 3 sides. Populations shown in white are exposed to the open ocean on at least 2 sides 
Table 1. Chlorostoma funebralis. Latitude and longitude for sampled populations. Protected (P) populations were enclosed on at least 3 sides, while exposed (E) sites were open to the open ocean on 2 or more sides. Coefficient of variation (CV) measured as a percentage of size distribution of populations

\begin{tabular}{|c|c|c|c|c|}
\hline Site & $\begin{array}{l}\text { Exposed or } \\
\text { protected }\end{array}$ & $\begin{array}{c}\text { Latitude } \\
\text { (N) }\end{array}$ & $\begin{array}{l}\text { Longitude } \\
\text { (W) }\end{array}$ & $\begin{array}{l}\mathrm{CV} \\
(\%)\end{array}$ \\
\hline Indian Beach & E & $45^{\circ} 55^{\prime} 05^{\prime \prime}$ & $123^{\circ} 58^{\prime} 44^{\prime \prime}$ & 40 \\
\hline Boiler Bay & $\mathrm{P}$ & $44^{\circ} 49^{\prime} 47^{\prime \prime}$ & $124^{\circ} 03^{\prime} 33^{\prime \prime}$ & 96 \\
\hline Devil's Punchbowl & E & $44^{\circ} 44^{\prime} 46^{\prime \prime}$ & $124^{\circ} 03^{\prime} 50^{\prime \prime}$ & 67 \\
\hline Strawberry Hill & E & $44^{\circ} 15^{\prime} 14^{\prime \prime}$ & $124^{\circ} 06^{\prime} 43^{\prime \prime}$ & 41 \\
\hline Lighthouse Beach & $\mathrm{P}$ & $43^{\circ} 20^{\prime} 25^{\prime \prime}$ & $124^{\circ} 22^{\prime} 30^{\prime \prime}$ & 85 \\
\hline Sunset Bay & $\mathrm{P}$ & $43^{\circ} 20^{\prime} 00^{\prime \prime}$ & $124^{\circ} 22^{\prime} 32^{\prime \prime}$ & 135 \\
\hline Ezzy Cove & $\mathrm{P}$ & $43^{\circ} 19^{\prime} 56^{\prime \prime}$ & $124^{\circ} 22^{\prime} 40^{\prime \prime}$ & 123 \\
\hline Middle Cove & $\mathrm{P}$ & $43^{\circ} 18^{\prime} 17^{\prime \prime}$ & $124^{\circ} 24^{\prime} 02^{\prime \prime}$ & 64 \\
\hline South Cove & $\mathrm{P}$ & $43^{\circ} 18^{\prime} 12^{\prime \prime}$ & $124^{\circ} 23^{\prime} 56^{\prime \prime}$ & 108 \\
\hline Cape Blanco & E & $42^{\circ} 50^{\prime} 17^{\prime \prime}$ & $124^{\circ} 33^{\prime} 37^{\prime \prime}$ & 60 \\
\hline Nellie's Cove & $\mathrm{P}$ & $42^{\circ} 44^{\prime} 25^{\prime \prime}$ & $124^{\circ} 33^{\prime} 37^{\prime \prime}$ & 45 \\
\hline Port Orford & E & $42^{\circ} 44^{\prime} 17^{\prime \prime}$ & $124^{\circ} 29^{\prime} 57^{\prime \prime}$ & 40 \\
\hline Mt. Humbug & E & $42^{\circ} 42^{\prime} 51^{\prime \prime}$ & $124^{\circ} 27^{\prime} 14^{\prime \prime}$ & 8 \\
\hline Lone Ranch & E & $42^{\circ} 05^{\prime} 58^{\prime \prime}$ & $124^{\circ} 20^{\prime} 42^{\prime \prime}$ & 81 \\
\hline Harris Beach & $\mathrm{P}$ & $42^{\circ} 03^{\prime} 57^{\prime \prime}$ & $124^{\circ} 18^{\prime} 33^{\prime \prime}$ & 132 \\
\hline Crescent City & E & $41^{\circ} 45^{\prime} 19^{\prime \prime}$ & $124^{\circ} 13^{\prime} 12^{\prime \prime}$ & 82 \\
\hline Patrick's Point & E & $41^{\circ} 07^{\prime} 48^{\prime \prime}$ & $124^{\circ} 09^{\prime} 53^{\prime \prime}$ & 81 \\
\hline Shelter Cove & $\mathrm{P}$ & $40^{\circ} 01^{\prime} 21^{\prime \prime}$ & $124^{\circ} 04^{\prime} 00^{\prime \prime}$ & 88 \\
\hline Laguna Point & E & $39^{\circ} 29^{\prime} 23^{\prime \prime}$ & $123^{\circ} 48^{\prime} 18^{\prime \prime}$ & 104 \\
\hline Point Dume & E & $34^{\circ} 00^{\prime} 11^{\prime \prime}$ & $118^{\circ} 48^{\prime} 18^{\prime \prime}$ & 150 \\
\hline Eréndira & $\mathrm{P}$ & $31^{\circ} 17^{\prime} 23^{\prime \prime}$ & $116^{\circ} 24^{\prime} 14^{\prime \prime}$ & 63 \\
\hline El Soccorito & E & $30^{\circ} 17^{\prime} 19^{\prime \prime}$ & $115^{\circ} 48^{\prime} 31^{\prime \prime}$ & 94 \\
\hline
\end{tabular}

cant $\left(F_{\mathrm{s}}=5.346, \mathrm{df}=1, \mathrm{p}=0.034\right)$, and the interaction term increased in significance $\left(F_{\mathrm{s}}=7.169, \mathrm{df}=1, \mathrm{p}=\right.$ 0.016). In a 1-way ANOVA testing coastal topography in the northern portion of the range, the significance of coastal topography increased with the removal of Nellie's Cove $\left(F_{\mathrm{s}}=19.283, \mathrm{df}=1, \mathrm{p}=0.001\right)$.

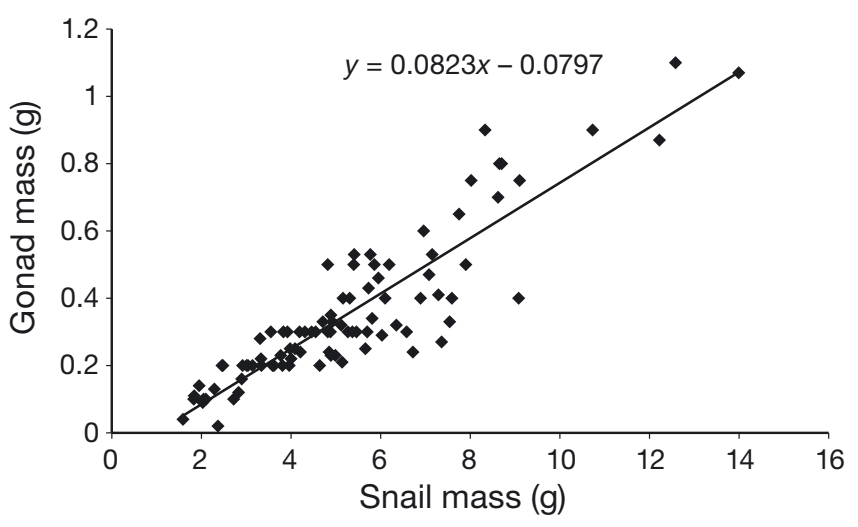

Fig. 4. Chlorostoma funebralis. A significant linear regression was found between the total mass of a female and the mass of the gonad $\left(p<0.0001, R^{2}=0.832\right)$

\section{Proportion of large adults}

The distribution of individuals $10 \mathrm{yr}$ of age ( $>9 \mathrm{~g}$ ) and older had the same pattern as percentage of juveniles and CV in the 2-way ANOVA. There was no significant difference in the percentage of older individuals between exposed and protected sites $\left(F_{\mathrm{s}}=0.092, \mathrm{df}=1\right.$, $p=0.765)$, but there was a significant difference between north and south $\left(F_{\mathrm{s}}=9.307, \mathrm{df}=1, \mathrm{p}=0.007\right)$, with a non-significant interaction factor $\left(F_{\mathrm{s}}=1.627, \mathrm{df}=\right.$ $1, p=0.218$ ). However, there was no difference between protected and exposed sites in the northern portion of the study, tested with a 1-way ANOVA $\left(F_{\mathrm{s}}=\right.$ $1.141, \mathrm{df}=1, \mathrm{p}=0.308$ ). When northern and southern sites were compared with a 1-way ANOVA without coastal topography as a factor, there were significantly more large individuals in the northern portion of the range $\left(F_{\mathrm{s}}=10.686, \mathrm{df}=1, \mathrm{p}=0.004\right)$.

\section{Reproductive output}

Females with a mass $\leq 2 \mathrm{~g}$, or about $14 \mathrm{~mm}$ in diameter, did not have fully developed gonads. In Chlorostoma funebralis females larger than $2 \mathrm{~g}$, gonad mass increased linearly with increasing snail mass ( $\mathrm{p}<$ $0.0001, R^{2}=0.832$, Fig. 4). Snail mass and diameter are strongly correlated, so snail diameter also had a significant regression with gonad mass $\left(p<0.0001, R^{2}=\right.$ 0.730 ). The concentration of eggs within gonads did not vary significantly with size, so the number of eggs produced by a female (extrapolated from gonad mass) increases linearly with snail weight $\left(\mathrm{p}<0.0001, \mathrm{R}^{2}=\right.$ 0.337, Fig. 5).

To quantify potential egg production for populations, the number of eggs produced by each size class was calculated. The relative abundance of each size class in

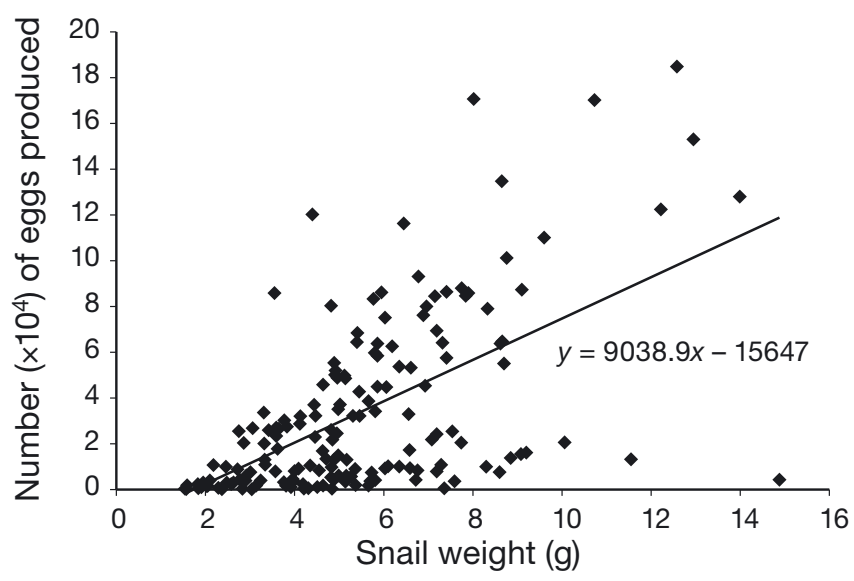

Fig. 5. Chlorostoma funebralis. A significant linear regression was found between the total mass of a female and the total number of eggs produced $\left(p<0.0001, R^{2}=0.337\right)$ 


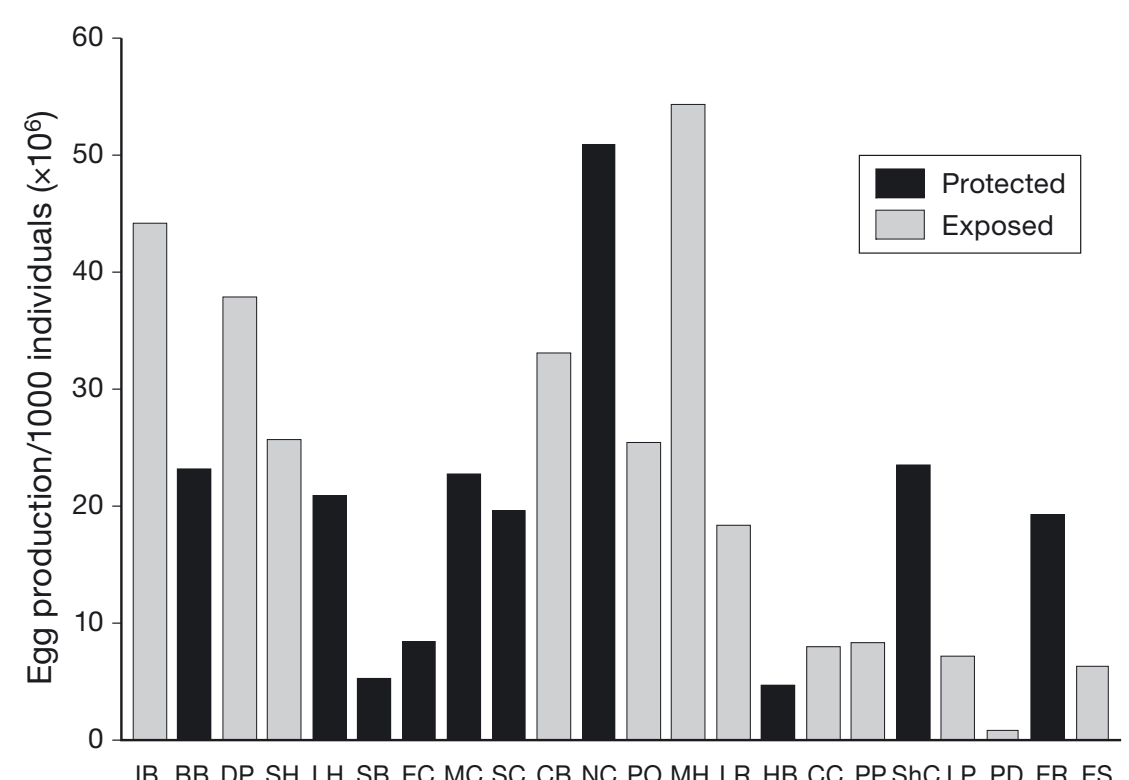

Fig. 6. Chlorostoma funebralis. Egg production (in millions) per 1000 individuals of populations, displayed from highest to lowest latitude, left to right. Egg production is calculated by gonad size and population size-frequency distribution. Northern sites are defined as north of Lone Ranch. IB = Indian Beach; BB = Boiler Bay; $\mathrm{DP}=$ Devil's Punchbowl; $\mathrm{SH}=$ Strawberry Hill $; \mathrm{LH}=$ Lighthouse Beach $;$ SB = Sunset Bay; $\mathrm{EC}=$ Ezzy Cove $; \mathrm{MC}=$ Middle Cove $; \mathrm{SC}=$ South Cove $; \mathrm{CB}=$ Cape Blanco $; \mathrm{NC}=$ Nellie's Cove $; \mathrm{PO}=$ Port Orford $; \mathrm{MH}=$ Mount Humbug $; \mathrm{LR}=$ Lone Ranch; HB = Harris Beach; $\mathrm{CC}=$ Crescent City; PP = Patrick's Point; ShC $=$ Shelter Cove $; \mathrm{LP}=$ Laguna Point $; \mathrm{PD}=$ Point Dume $; \mathrm{ER}=$ Eréndira $; \mathrm{ES}=\mathrm{El}$ Soccorito
Boiler Bay and South Cove, also have a small percentage of larger individuals which will produce large numbers of eggs. The average egg production per 1000 individuals in the northern portion of the study was $2.75 \times 10^{7}$.

In the 2-way ANOVA without Nellie's Cove, latitudinal region was significant $\left(F_{\mathrm{s}}=13.487\right.$, df $\left.=1, \mathrm{p}=0.002\right)$ while coastal topography was not $\left(F_{\mathrm{s}}=\right.$ 2.505, $\mathrm{df}=1, \mathrm{p}=0.132$ ). The interaction in the 2-way ANOVA was more significant than when Nellie's Cove was included $\left(F_{\mathrm{s}}=12.089\right.$, df $=1, \mathrm{p}=0.003$, from $\mathrm{p}=0.037$ ). This was because removing Nellie's Cove increased the overall difference between exposed and protected sites in the northern portion of the range.

When comparing northern and southern regions without using coastal topography as a factor, egg production was significantly higher in the northern populations $\left(F_{\mathrm{S}}=10.740, \mathrm{df}=\right.$ $1, p=0.004)$. In the southern portion of the study, populations were heavily skewed towards pre-reproductive juveniles and small adults, which contribute little to the total egg production a population was calculated from the size-frequency distribution of the population and then standardized for 1000 individuals (Fig. 6). The sum of egg production for an average representation of 1000 individuals was used as the relative egg production for each population.

Larger individuals have the potential to produce more eggs than smaller individuals. Populations with a higher percentage of large individuals should produce more eggs per 1000 individuals than populations skewed towards the smaller size classes. In a 2-way ANOVA, exposure was not significant $\left(F_{\mathrm{S}}=0.546\right.$, df $=$ $1, \mathrm{p}=0.469)$ while latitudinal region $\left(F_{\mathrm{s}}=11.411, \mathrm{df}=1\right.$, $\mathrm{p}=0.003)$ and the interaction between factors were significant $\left(F_{\mathrm{s}}=5.057, \mathrm{df}=1, \mathrm{p}=0.037\right)$.

Egg production was not significantly different between coastal topographies in the north $\left(F_{\mathrm{S}}=4.229, \mathrm{df}=\right.$ $1, \mathrm{p}=0.064)$ or in the south $\left(F_{\mathrm{s}}=2.293\right.$, df $=1, \mathrm{p}=$ 0.174). However, when Nellie's Cove was excluded from this analysis, the difference between exposed and protected sites in the north becomes highly significant $\left(F_{\mathrm{s}}=12.983, \mathrm{df}=1, \mathrm{p}=0.005\right)$. In the northern portion of the study, exposed populations had high percentages of large individuals that contribute to the relative egg production of the population. Protected sites in the northern portion of the study are skewed towards the juvenile size classes but some populations, such as of the population. The average egg production per 1000 individuals in the southern portion of the study was 9.72 $\times 10^{6}$, an order of magnitude lower than that of populations in the north.

\section{DISCUSSION}

The structure of populations of Chlorostoma funebralis varies with both coastal topography and latitude. Coastal topography was a significant factor only in the northern portion of the present study. In the northern region, populations in protected areas show a much higher percentage of juveniles than exposed populations, which are skewed toward large adults. In the southern portion of the study, population structure did not vary with coastal topography, and all populations were primarily composed of juveniles.

These observed patterns are most likely due to the combination of several factors. One component of sizefrequency distributions, the presence or absence of juveniles, is due to factors affecting recruitment such as larval supply and post-settlement mortality. In contrast, the distribution of adults in populations is due to the sum of numerous factors. The number of adults in a population is a reflection of recruitment events in past 
years, as well as mortality due to predation and physical stress that has occurred during the intervening years.

An absence of juveniles in exposed populations may be caused by low and/or irregular larval supply, a failure of larvae to survive metamorphosis (settlement), or high mortality rates of newly metamorphosed juveniles. Protected sites may have had more juveniles because larval supply is high and populations experience high settlement with little inter-annual variation. Exposed sites may have low larval supply due to movement of larvae offshore, punctuated with occasional years of high settlement. This pattern of high interannual variation would result in populations where juveniles are rare except during certain years. This is one potential mechanism that would create the sizefrequency distributions described by this study.

Larval supply may drive patterns of recruitment. Several studies have shown relationships between protected bays and coves and larval retention (Archambault et al. 1998, Archambault \& Bourget 1999, Shanks et al. 2003, McQuaid \& Phillips 2006). The hydrography of protected areas may retain larvae for long enough periods that larvae are unable to disperse outside of the protected area on a large scale. Many studies of larval dispersal and retention have focused on species with larval periods of weeks, such as mussels and barnacles (Menge et al. 2004, Shanks \& Brink 2005, McQuaid \& Phillips 2006). The shorter larval period of Chlorostoma funebralis (5 to $8 \mathrm{~d}$ ) should amplify the effects of retention since there will be less time and opportunity for hydrographic conditions to change and for larvae to move offshore. Topographically generated fronts at the mouth of protected bays and coves can last for days (Shanks et al. 2003), long enough to retain $C$. funebralis for the entirety of its larval period. Larval retention would increase larval supply, and the resulting recruitment rate should be higher and have lower inter-annual variation.

Studies with mussels show a positive correlation between high recruitment and gamete production within a protected population (McQuaid \& Phillips 2006). This pattern may be due to larval retention that causes high reproductive effort to result in high larval supply in the same region. This previously described pattern is unlikely to be mechanistically similar to patterns observed in Chlorostoma funebralis. In the present study, the highest reproductive effort was observed in exposed, northern populations with the fewest juveniles. If reproductive effort was directly tied to larval supply and recruitment as described by McQuaid \& Phillips (2006), exposed populations with the largest individuals would also have large numbers of juveniles.

If the large numbers of juveniles in protected habitats north of Brookings, Oregon, were due to larval retention within bays and coves, the lack of juveniles in most exposed populations may be due to larval movement offshore. Populations at exposed sites have few individuals in the juvenile size classes, indicating poor recruitment in the previous years. Several exposed sites, such as Indian Beach and Devil's Punchbowl, have multiple peaks in the size-frequency distribution (Fig. 3). If these peaks reflect years of high recruitment separated by gaps of poor recruitment, these populations have high inter-annual variation in recruitment. Exposed sites experience more wave energy, which may wash larvae away from the parental site, and larvae are only moved onshore at these sites during years when hydrographic conditions move larvae onshore during the spawning period. Some species in the genus Tegula spawn during major wave events in Japan (Sasaki \& Shepherd 1995) and return to shore, potentially by remaining within local wave-generated circulation cells. If Chlorostoma funebralis larvae have similar methods for remaining close to shore, larval supply may remain high annually, and inter-annual variation in recruitment may be due to inter-annual variation in post-settlement mortality.

The population in Nellie's Cove was different from all other protected sites in the north. Other protected populations in the northern portion of this study had a large portion of the population in the juvenile size classes, and few large adults. Nellie's Cove, in contrast, had a protected population with no juveniles and a high percentage of large adults. Nellie's Cove is a south-facing cove on the south face of Port Orford Headlands. This site is protected during the summer, when wave energy is primarily from the north (Shanks et al. 2003), but is exposed to storm waves from the south in the fall and winter; it is the only protected site in this study that is exposed to storms from the south in the fall. Chlorostoma funebralis larvae are expected to be in the water column between August and October in northern populations (Belcik 1965, Paine 1971, Moran 1997); hence, the period of storm waves may overlap with the spawning window, preventing larval retention in an otherwise protected site.

Differences in recruitment between protected and exposed populations may also be due to post-settlement mortality. The small size of recently metamorphosed individuals and the chance of post-settlement mortality make the youngest juveniles difficult to enumerate. Chlorostoma funebralis size at metamorphosis is between 240 and $260 \mu \mathrm{m}$ (Moran 1997, Guzmán del Próo et al. 2006) and the smallest individuals collected in this study were approximately $500 \mu \mathrm{m}$. Using juvenile growth rates observed in the laboratory, the smallest juveniles collected in this study may be between 2 and 6 mo old (Moran 1997, Guzmán del Próo et al. 2006). The smallest individuals sampled had settled months 
before they were counted; hence, we cannot differentiate between the effects of larval supply and variation in mortality in the first few months after metamorphosis on the population structure.

Variation in post-settlement mortality may be caused by differences in juvenile habitat between protected and exposed sites that exist only within the northern portion of the population. These differences may include wave energy, which may cause differences in temperature, oxygen levels, sedimentation, food availability and sediment movement. However, juveniles are found in the high intertidal, exclusively in coarse sediment under boulders and very protected cracks on rocks (authors' pers. obs.). There is no immediately obvious biotic or abiotic factor within this micro-habitat that would differ systematically between protected and exposed populations.

South of Brookings, Oregon, all populations sampled showed similar size-frequency distributions; the distributions were heavily skewed towards juvenile Chlorostoma funebralis. No difference is apparent between northern and southern California and Baja California. This pattern was also observed by Frank (1975), who proposed that in the southern portion of the species range, individuals have shorter life spans, faster growth rates, and reproduce throughout the year rather than at an annual spawning event as in the north. In southern California, a conjoining species, $C$. (Tegula) eiseni, spawns and recruits throughout the year (Wolf 1991). In Oregon and Washington, C. funebralis spawns in late summer or fall (Belcik 1965, Paine 1971, Moran 1997); spawning of C. funebralis has not been studied in California and the species may show variation in reproductive strategy in different latitudinal regions. If, like C. eiseni, C. funebralis in California reproduce throughout the year, they may be using a reproductive strategy which allows for more opportunities to spawn during hydrographic conditions which allow larvae to remain close to shore, regardless of local coastal topography.

Reproduction independent of seasonality may be necessary for Chlorostoma funebralis in the southern portions of its range. By reducing inter-annual variation in recruitment success, C. funebralis populations in the south may be sustained despite the shorter life span of individuals indicated by growth rate data (Frank 1975) and the size-frequency distributions from populations sampled in California. Individuals in central and southern California rarely live past 7 yr (Frank 1975), so inter-annual variation in recruitment must be dampened in comparison to populations in Oregon, where individuals may live up to $30 \mathrm{yr}$ (Frank 1975) and so have many more years to attempt reproductive success. Further studies of the reproductive and recruitment seasonality on a latitudinal gradient are nec- essary to determine if $C$. funebralis are reproducing year-round in the southern portion of the species range and annually in the northern portion of the range.

Differences in population structure may also be due to differences in predation rates. Juvenile Chlorostoma funebralis are found in the high intertidal (Paine 1971, Frank 1975, Moran 1997), generally above the tidal height of the adult predators, so it is unlikely that these predators have an effect on the number of juveniles in a population. The main predators through the species range of $C$. funebralis are the seastar Pisaster ochraceus and crabs of the genus Cancer. In southern California, intertidal octopus Octopus bimaculoides and $O$. bimaculatus are also important predators (Fawcett 1984). P. ochraceus and Cancer spp. abundances do not vary on a latitudinal gradient (Fawcett 1984), but the added predation pressure of Octopus spp. in southern California and Baja California may cause the absence of larger $C$. funebralis in those populations. Predation pressure of $P$. ochraceus and Cancer spp. may vary along the Oregon coast, which could explain why some populations, such as Devil's Punchbowl and Cape Blanco, have many large individuals, while other populations, such as Sunset Bay have very few large individuals. No studies have identified potential predators on the juvenile stages of $C$. funebralis, which will be necessary to fully understand the effects of predation on population structure.

Although 2 latitudinal regions are clear from the data collected in this study, they do not conform to the predictions of population structure on a latitudinal gradient predicted by upwelling regions. The intermittent upwelling during summers north of Cape Blanco has been hypothesized to move larvae offshore during upwelling and transport them back toward shore during relaxation of upwelling (Roughgarden et al. 1988, Menge et al. 2004). It has been hypothesized that constant upwelling south of Cape Blanco offers few opportunities for larvae to return to shore, leading to low recruitment with high inter-annual variation. In contrast, the data collected in this study show high recruitment success in California and southern Oregon, where upwelling is more persistent. North of Brookings, Oregon, where upwelling is more variable, population structure varies with coastal topography. Chlorostoma funebralis may not be as affected by upwelling patterns as other species with longer larval periods. Surviving larvae of $C$. funebralis may be retained close to shore and metamorphose before they are moved far offshore. If the larvae are transported offshore by any mechanism, the larval period will not last long enough to allow a return to shore.

Population structure of Chlorostoma funebralis varies both with coastal topography and latitude. Numerous factors such as local hydrodynamics, post-settlement 
mortality, and predation may all contribute to the observed patterns. Local, small-scale processes may be important in determining larval settlement and population dynamics, but this spatial scale is often ignored in favor of large-scale observations on a latitudinal gradient. Without further studies that use both meso- and large-scale observations, we will not be able to understand the relative importance of these factors.

Acknowledgements. We thank Jonathan Shockley, Justin Lovero, Ben Grupe, and the students at OIMB who assisted with the field work for this project.

\section{LITERATURE CITED}

Archambault P, Bourget E (1999) Influence of shoreline configuration on spatial variation of meroplanktonic larvae, recruitment and diversity of benthic subtidal communities. J Exp Mar Biol Ecol 238:161-184

Archambault P, Roff JC, Bourget E, Bang B, Ingram GR (1998) Nearshore abundance of zooplankton in relation to shoreline configuration and mechanisms involved. J Plankton Res 20(4):671-690

Barth JA, Pierce SD, Smith RL (2000) A separating coastal upwelling jet at Cape Blanco, Oregon and its connection to the California Current System. Deep-Sea Res 47:783-810

Belcik FP (1965) Note on a range extension and observations of spawning in Tegula, a Gastropod. Veliger 7:233-234

Darby RL (1964) On growth and longevity in Tegula funebralis. Veliger 6S:5-7

Ebert TA (1983) Recruitment in echinoderms. In: Jangoux M, Lawrence J (eds) Echinoderm studies, Vol 1. Balkema, Rotterdam, p 169-203

Ebert TA, Russell MP (1988) Latitudinal variation in size structure of the west coast purple sea urchin: a correlation with headlands. Limnol Oceanogr 33:286-294

Fawcett MH (1984) Local and latitudinal variation in predation on an herbivorous marine snail. Ecology 65: 1214-1230

Frank PW (1975) Latitudinal variation in the life history features of the black turban snail Tegula funebralis (Prosobranchia: Trochidae). Mar Biol 31:181-192

Gaines SD, Bertness MD (1992) Dispersal of juveniles and variable recruitment in sessile marine species. Nature 360:579-580

Guzmán del Próo SA, Reynoso-Granados T, MonsalvoSpencer P, Serviere-Zaragoza E (2006) Larval and early juvenile development in Tegula funebralis (Adams, 1855) (Gastropoda: Trochidae) in Baja California Sur, México. Veliger 48:116-120

McCulloch A, Shanks AL (2003) Topographically generated fronts, very nearshore oceanography and the distribution and settlement of mussel larvae and barnacle cyprids. J Plankton Res 25:1427-1439

McQuaid CD, Phillips TE (2006) Mesoscale variation in reproduction, recruitment and population structure of intertidal mussels with low larval input: a bay/coast comparison.

Editorial responsibility: Steven Morgan,

Bodega Bay, California, USA
Mar Ecol Prog Ser 327:193-206

Menge BA, Blanchette C, Raimondi P, Freidenburg T and others (2004) Species interaction strength: testing model predictions along an upwelling gradient. Ecol Monogr 74: $663-684$

Moran AL (1997) Spawning and larval development of the black turban snail Tegula funebralis (Prosobranchia: Trochidae). Mar Biol 128:107-114

Morgan LE, Wing SR, Botsford LW, Lundquist CJ, Diehl, JM (2000) Spatial variability in red sea urchin (Strongylocentrotus franciscanus) recruitment in northern California. Fish Oceanogr 9:83-98

> Morgan SG, Fisher JL, Mace AL, Akins L, Slaughter AM, Bollens SM (2009a) Cross-shelf distributions and recruitment of crab postlarvae in a region of strong upwelling. Mar Ecol Prog Ser 380:173-185

Morgan SG, Fisher JL, Miller SH, McAfee ST, Largier JL (2009b) Nearshore larval retention in a region of strong upwelling and recruitment limitation. Ecology 90: 3489-3502

Morris RH, Abbott DP, Harderlie EC (1980) Intertidal invertebrates of California. Stanford University Press, Stanford, CA

Paine RT (1971) Energy flow in a natural population of the herbivorous gastropod Tegula funebralis. Limnol Oceanogr 16:86-98

$>$ Poulin E, Palma AT, Leiva G, Narvaez D, Pacheco R, Navarrete SA, Castilla JC (2002) Avoiding offshore transport of competent larvae during upwelling events: the case of the gastropod Concholepas concholepas in Central Chile. Limnol Oceanogr 47:1248-1255

Rasband WS (1997-2008) ImageJ. US National Institutes of Health, Bethesda, MD, available at http://rsb.info.nih. gov/ij/

Roughgarden J, Gaines S, Possingham H (1988) Recruitment dynamics in complex life cycles. Science 241:1460-1466

Sasaki R, Shepherd SA (1995) Larval dispersal and recruitment of Haliotis discus hannai and Tegula spp. on Miyagi coasts, Japan. Mar Freshw Res 46:519-529

Shanks AL (2009) Pelagic larval duration and dispersal distance revisited. Biol Bull 216:373-385

Shanks AL, Brink L (2005) Upwelling, downwelling, and cross-shelf transport of bivalve larvae: test of a hypothesis. Mar Ecol Prog Ser 302:1-12

Shanks AL, Shearman RK (2009) Paradigm lost? Cross-shelf distributions of intertidal invertebrate larvae are unaffected by upwelling or downwelling. Mar Ecol Prog Ser 385:189-204

Shanks AL, Grantham BA, Carr MH (2003) Propagule dispersal distance and the size and spacing of marine reserves. Ecol Appl 13(1S):S159-S169

von der Meden CEO, Porri F, Erlandsson J, McQuaid CD (2008) Coastal topography affects the distribution of indigenous and invasive mussels. Mar Ecol Prog Ser 372: 135-145

Wolf JM (1991) Population characteristics of Tegula eiseni in the lower Southern California Bight. MS thesis, San Diego State University, CA

Wright RC (1975) Variations in size structure along a latitudinal cline, growth rate and respiration in the snail Tegula funebralis. MS thesis, San Diego State University, CA

Submitted: February 9, 2010; Accepted: December 11, 2010 Proofs received from author(s): February 21, 2011 